\title{
Nilai Karakter Disiplin dan Tanggung Jawab Pada Tembang Dolanan Menthok-Menthok dan Gugur Gunung
}

\author{
Pri Okta Priani ${ }^{1 *}$, Purwadi ${ }^{2}$, Mei Fita Asri Untari ${ }^{3}$ \\ 1,2,3 Universitas PGRI Semarang \\ Semarang, Indonesia \\ *Email: Priani887@gmail.com
}

\begin{abstract}
Permasalahan yang terjadi yaitu kurangnya sikap disiplin dan tanggung jawab pada peserta didik. Alasan yang mendasari peserta didik banyak yang melakukan pelanggaran adalah mereka tidak paham akan bahayanya tidak menggunakan masker saat pandemi seperti sekarang. Penelitian ini bertujuan untuk menganalisis nilai karakter disiplin dan tanggung jawab pada tembang dolanan "Menthok-Menthok" dan "Gugur Gunung". Jenis penelitian ini adalah kualitatif deskriptif. Subjek penelitian ini adalah Kepala Sekolah dan Guru. Teknik pengumpulan data yang digunakan meliputi wawancara dan dokumentasi. Instrumen pada penelitian ini adalah daftar pertanyaan wawancara untuk Kepala Sekolah dan Guru. Teknik analisis data menggunakan reduksi data. Hasil penelitian menunjukkan bahwa pada tembang dolanan "Mnethok-Menthok" dan "Gugur Gunung" banyak mengandung nilai karakter disiplin dan tanggung jawab serta terselip nilai karaktergotong royong bagi pembentukan karakter peserta didik. Implikasi penelitian ini diharapkan dapat meningkatkan disiplin siswa melalui kearifan local seperti tembang doladan.
\end{abstract}

Kata Kunci: Nilai, Karakter, Tembang Dolanan

\begin{abstract}
The problem that occurs is the lack of discipline and responsibility in students. The reason behind many students committing violations is that they do not understand the dangers of not wearing masks during a pandemic like now. This study aims to analyze the character values of discipline and responsibility in the dolanan songs "Menthok-Menthok" and "Gugur Gunung". This type of research is descriptive qualitative. The subjects of this research are the Principal and Teachers. Data collection techniques used include interviews and documentation. The instrument in this study was a list of interview questions for principals and teachers. The data analysis technique uses data reduction. The results showed that the songs "Mnethok-Menthok" and "Gugur Gunung" contained many values of discipline and responsibility, as well as the value of mutual cooperation for character building of students. The implications of this research are expected to improve student discipline through local wisdom such as the doladan song.
\end{abstract}

Keywords: Value, Chacarter, Song of the Dolanan

\section{PENDAHULUAN}

Pendidikan bertujuan untuk berkembangnya potensi peserta didik agar menjadi manusia yang beriman dan bertaqwa kepada Tuhan Yang Maha Esa, berakhlak mulia, sehat, berilmu, cakap, kreatif, mandiri dan menjadi warga negara yang demokratis serta bertanggung jawab (Muhamad Nova, 2017; Pitaloka et al., 2021). Oleh karena itu pendidikan diciptakan tidak hanya bertujuan untuk memberi ilmu pengetahuan kepada peserta didik tetapi juga bertujuan untuk mengembangkan kreatifitas dan membina sikap kepribadian pada diri seseorang, sehingga akan seimbang antara ilmu pengetahuan dan jiwa yang berkarakter. Pendidikan mempunyai peran penting dalam pembentukan karakter. Pada era globalisasi seperti sekarang, teknologi yang berkembang dapat mengakibatkan hilangnya karakter pada peserta didik (Pakpahan \& Fitriani, 2020; Yulianti et al., 2016). Karakter tersebut dapat hilang karena banyak anak yang lebih tertarik

${ }^{*}$ Corresponding author.

Received March 03, 2021; Accepted April 12, 2021; Available online April 25, 2021

(C) 2020 IVCEJ. All Rights Reserved

Indonesian Values and Character Education Journal (IVCEJ) | 28 
pada perkembangan teknologi. Saat ini pendidikan karakter sedang digalakkan di Indonesia. Hal ini bertujuan agar masyarakat tidak kehilangan jati diri.

Berdasarkan wawancara yang dilakukan oleh peneliti dengan Bapak Sukanto selaku Kepala Sekolah, Bapak Suripan selaku Guru Kelas 6 dan Ibu Nyamiati selaku Guru Kelas 2 di SD Negeri 2 Sendangwungu Kecamatan Banjarejo, pada kondisi pandemi seperti sekarang, peneliti menemukan permasalahan kurangnya sikap disiplin dan tanggung jawab pada peserta didik kelas II dan VI. SDN 2 Sendangwungu Kecamatan Banjarejo menerapkan sistem rolling dalam pembelajaran. Sistem rolling dilakukan setiap hari, dimana dalam satu hari terdapat satu kelas yang masuk. Pembelajaran dilakukan selama satu jam dalam sehari mulai pukul 08.0009.00 WIB. Pada saat kegiatan belajar didalam kelas banyak peserta didik yang melakukan pelanggaran kedisiplinan dan tanggung jawab. Pelanggaran kedisiplinan yang dilakukan antara lain peserta didik tidak menggunakan masker, didik tidak mencuci tangan dan peserta didik tidak menjaga jarak dengan peserta didik lain. Alasan yang mendasari peserta didik banyak yang melakukan pelanggaran adalah mereka tidak paham akan bahayanya tidak menggunakan masker saat pandemi seperti sekarang. Selain itu banyak peserta didik yang tidak mencuci tangan dan tidak menghiraukan untuk menjaga jarak karena mereka masih berfikir disaat mereka bertemu teman-temannya yang dilakukan hanya bermain. Walaupun sudah diperingatkan oleh guru tetapi mereka tidak menghiraukan. Sedangkan pelanggaran terhadap kurangnya tanggung jawab pada peserta didik antara lain peserta didik tidak mengumpulkan tugas tepat waktu, peserta didik tidak mengerjakan tugas sekolah dan tidak mengerjakan piket kelas harian. Alasan yang mendasari peserta didik melakukan pelanggaran pada tanggung jawab adalah tidak mengumpulkan tugas tepat waktu, hal itu disebabkan karena peserta didik berpikir besok bukan jadwal mereka masuk kelas, selain itu banyak orang tua yang tidak terlalu aktif pada grup kelas. Oleh karena itu guru menanamkan nilai karakter disiplin dan tanggung jawab pada peserta didik melalui tembang dolanan pada kelas rendah dan tinggi.

Solusi yang dapat mengatasi permasalahan tersebut yaitu dengan memberikan pendidikan karakter bagi siswa. Ada dua cara untuk mengajarkan membangun karakter. Cara pertama adalah melalui presentasi atau untuk membuat karakter yang menonjol dari apa yang harus dipahami oleh para peserta didik (Hidayah, 2015; Ramdhani et al., 2019). Cara kedua adalah melakukan tindakan. Setelah karakter ditanamkan pada siswa mereka akan menerapkan dalam perilaku mereka. Menerapkan nilai yang telah diperoleh peserta didik dapat dilakukan melalui permainan yang digabungkan dengan proses belajar mengajar, pengembangan kurikulum harus berakar pada budaya bangsa, kehidupan bangsa masa kini dan kehidupan bangsa dimasa mendatang (Wardani et al., 2019). Salah satu budaya tersebut meliputi permainan tradisional, tembang macapat, tembang dolanan dan kesenian tari. Karakter seorang manusia sangat erat kaitannya dengan agama, lingkungan dan budaya dimana ia tinggal dan dibesarkan. Pendidikan karakter juga dapat diselipkan melalui berbagai kesenian tradisional salah satunya melalui tembang dolanan.

Tembang dolanan merupakan salah satu sarana komunikasi dan sosialisasi anak-anak (Jawa) dengan lingkungannya. Melalui tembang dolanan itu guru dapat menanamkan nilai karakter pada anak-anak. Pada tembang dolanan terdapat pesan moral yang mendidik, sedangkan dalam bahasanya menggunakan bahasa yang sederhana sehingga mudah dihafalkan dan dicerna sesuai perkembangan jiwa anak (Arisyanto et al., 2021). Tembang dolanan terdapat pada mata pelajaran muatan lokal (mulok) pada pendidikan dasar yang telah berlaku sejak 1994. Tujuan program tersebut adalah memberikan pendidikan apresiasi seni kepada peserta didik Sekolah Dasar, agar seni tradisional tidak hilang dari budaya Jawa (Arifin et al., 2018; Nurohmah \& Dewi, 2021). Kurikulum muatan lokal disusun untuk mewujudkan pelestarian dan pengembangan serta memberikan ketrampilan berkesenian bagi peserta didik sebagai pewaris kebudayaan nenek moyang (Farid, 2012; Prayogi et al., 2019). Pembelajaran bahasa jawa merupakan salah satu mata pelajaran muatan lokal yang didalamnya mengandung nilai kearifan lokal dan nilai-nilai budi pekerti (Prayogi et al., 2019; Sukarniti, 2020). Pembelajaran tembang dolanan seharusnya disampaikan secara totalitas karena didalam materi ini mengandung banyak nilai-nilai luhur warisan nenek moyang yang mampu menyampaikan makna yang tersirat dalam setiap syair atau lirik.

Disiplin merupakan sikap dan perilaku yang menggambarkan kepatuhan kepada suatu aturan atau ketentuan (Nurwita, 2019; Puspawati, 2019). Sifat disiplin dapat dilaksanakan dengan mematuhi aturan yang sudah ditetapkan. Nilai pada hakikatnya adalah sifat atau kualitas yang melekat pada suatu objek, bukan objek itu sendiri. Misalnya, bunga itu indah, perbuatan itu susila. Susila adalah sifat atau kualitas yang melekat pada bunga dan perbuatan. Dengan demikian maka nilai itu sebenarnya adalah suatu kenyataan-kenyataan lainnya. Ada nilai itu karena adanya 
kenyataan-kenyataan lain sebagai pembawa nilai. Menilai berarti menimbang suatu kegiatan manusia untuk menghubungkan sesuatu dengan sesuatu yang lain, kemudian untuk selanjutnya diambil keputusan (Dozan \& Fitriani, 2020; Khusniati, 2014). Orang yang berkarakter berarti orang yang berkepribadian, berperilaku, bersifat, bertabiat, atau berwatak. Karakter dapat dimaknai sebagai nilai dasar yang membangun pribadi seseorang, berbentuk baik karena pengaruh hereditas maupun pengaruh lingkungan, yang membedakannya dengan orang lain, serta diwujudkan dalam sikap dan perilakunya dalam kehidupan sehari-hari (Gazali et al., 2019; Setyawan et al., 2017). Dalam penanaman karakter dapat dilakukan dengan cara melalui pembelajaran kebudayaan seperti tembang dolanan. Berdasarkan hal diatas, maka tujuan dalam penelitian ini yaitu untuk menganalisis nilai-nilai karakter disiplin dan tanggung jawab pada tembang dolanan "Menthok-Menthok" dan "Gugur Gunung".

\section{METODE}

mpulan data merupakan langkah yang paling strategis dalam penelitian, karena tujuan utama dari penelitian adalah mendapatkan data. Metode yang digunakan dalam pemgumpulan data dalam penelitian ini yaitu wawancara dan dokumentasi. Teknik pengumpulan data merupakan langkah yang paling utama dalam penelitian. Tanpa mengetahui teknik pengumpulan data, maka peneliti tidak akan mendapatkan data yang memenuhi standar yang ditetapkan. Pengumpulan data dapat dilakukan dengan berbagai setting, berbagai sumber dan berbagai cara. Bila dilihat dari sumber datanya, maka pengumpulan data dapat menggunakan sumber primer, sumber sekunder. Sumber primer adalah sumber data yang langsung memberikan sumber data kepada pengumpul data, dan data sekunder merupakan sumber data yang tidak langsung memberikan data kepada pengumpul data, seperti lewat orang lain atau lewat dokumen. Selanjutnya bisa dilihat dari segi cara atau teksnik pengumpulan data, maka teknik pengumpulan data dapat dilakukan dengan observasi, wawancara, angket, dokumentasi dan gabungan keempatnya. Tektik pengumpulan data yang digunakan peneliti yaitu metode obesrvasi, wawancara dan dokumentasi. Wawancara akan dilakukan secara tatap muka kepada beberapa informan seperti guru Sekolah Dasar Kelas II dan VI. Persiapan peneliti sebelum wawancara yaitu menyiapkan pedoman wawancara yang berisi sejumlah pertanyaan yang mengacu pada fakta, pengetahuan, pendapat atau persepsi, narasumber yang berkenan dengan fokus penelitian. Cara yang dilakukan yaitu wawancara terstruktur dengan cara peneliti merekam dan mencatat informasi penting yang diberikan oleh narasumber. Metode dokumentasi diperlukan guna menunjang berjalannya penelitian. Kegiatan tersebut yaitu mencari data mengenai hal-hal atau variabel yang berupa catatan, transkip, buku, surat kabar, majalah, prasasti, notulen dan sebagainya. Dokumen bisa berbentuk tulisan, gambar atau karya-karya instrumental dari seseorang. Penelitian ini menggunakan dokumen Buku Muatan Lokal Tembang Jawa yang diterbitkan oleh Dewan Bahasa Jawa Kabupaten Blora.

Data yang telah terkumpul dan dikelompokkan, maka langkah selanjutnya adalah analisis data. Analisis data adalah proses mencari dan meyusun secara sistematis data diperoleh dari hasil wawancara dan dokumentasi sehingga dapat dipahami dan temuannya dapat diinformasikan kepada orang lain. Langkah-langkah dalam analisis data yaitu reduksi data, penyajian data dan conclusion data atau verification. Mereduksi data berarti merangkum, memilih hal-halyang penting, dicari tema dan polanya. Data yang diperoleh dari lapangan jumlahnya cukup banyak, untuk itu perlu dibuat dan dicatat secara rinci. Dalam penelitian ini, peneliti mengambil nilai karakter dan kalimat yang menjelaskan nilai karakter tersebut, dengan mencatat nilai karakter yang terdapat pada tembang dolanan "Menthok-Menthok" dan "Gugur Gunung". Setelah data direduksi maka langkah selanjutnya adalah menyajikan data. Penyajian data adalah cara yang dilakukan untuk memudahkan dalam memahami apa yang terjadi, merencanakan kerja selanjutnya berdasarkan apa yang telah dipahami. Pengelompokan nilai karakter disiplin dan tanggung jawab pada setiap lirik yang yang terdapat pada tembang dolanan "Menthok-Menthok" dan "Gugur Gunung". Menjabarkan hasil wawancara dengan kepala sekolah, guru kelas 2 dan 6 tentang penerapan nilai karakter yang terdapat pada tembang dolanan "Menthok-Menthok" dan "Gugur Gunung".

\section{HASIL DAN PEMBAHASAN}

Hasil

Berdasarkan analisis data nilai karakter disiplin dan tanggung jawab pada tembang dolanan "Menthok-Menthok" dan "Gugur Gunung". Nilai karakter yang digunakan dalam 
penerapan tersebut berhubungan erat dengan nilai karakter yang terkandung dalam tembang dolanan. Hal itu dikarenakan pada tembang dolanan penggunaan bahasa yang mudah dipahami dan juga dibantu diterjemahkan oleh guru. Dalam penerjemahannya guru menggunakan bahasa jawa yang digunakan sehari-hari agar peserta didik paham tentang kandungan nilai karakter dalam tembang dolanan. Pada penelitian menggunakan kamus online karena untuk menunjang sumber-sumber data yang dibutuhkan. Penelitian ini menyajikan hasil analisis nilai karakter pada tembang dolanan "Menthok-Menthok" dan "Gugur Gunung" yang temuat dalam Buku Muatan Lokal Tembang Jawa yang diterbitkan oleh Dewan Bahasa Jawa Kabupaten Blora. Berikut adalah nomor serta teks tembang dolanan beserta terjemahannya yang telah dianalisis oleh penulis. Analisis nilai karakter tembang dolanan. Terdapat nilai karakter yang terkandung dalam tembang dolanan "Menthok-Menthok".

Tabel 1. Analisis Nilai Karakter yang Terdapat dalam Tembang Dolanan

\begin{tabular}{|c|c|c|c|}
\hline No & Lirik tembang & Terjemahan & Nilai karakter \\
\hline 1. & $\begin{array}{l}\text { Menthok-menthok tak } \\
\text { kandani }\end{array}$ & $\begin{array}{l}\text { Menthok-menthok kuberi } \\
\text { tahu }\end{array}$ & $\begin{array}{l}\text { - } \\
\text { (Tidak mengandung nilai } \\
\text { karakter tetapi mengacu pada } \\
\text { memberi nasihat atau sindiran) }\end{array}$ \\
\hline 2. & $\begin{array}{l}\text { Mung rupamu } \\
\text { angisin-isini }\end{array}$ & $\begin{array}{l}\text { Wajahmu hanya } \\
\text { memalukan }\end{array}$ & $\begin{array}{l}\text { - } \\
\text { (Tidak mengandung nilai } \\
\text { karakter tetapi mengacu pada } \\
\text { sindiran secara halus) }\end{array}$ \\
\hline 3. & Mbokya ojo ngetok & $\begin{array}{l}\text { Seharusnya jangan } \\
\text { kelihatan }\end{array}$ & $\begin{array}{l}\text { Tanggung jawab } \\
\text { Disiplin }\end{array}$ \\
\hline 4. & Ana kandhang wae & Didalam kandang saja & Tanggung jawab \\
\hline 5. & Enak-enak ngorok & Enak-enak tidur & Disiplin \\
\hline 6. & Ora nyambut gawe & Tidak usah bekerja & Disiplin \\
\hline 7. & $\begin{array}{l}\text { Menthok-menthok } \\
\text { mung lakumu }\end{array}$ & $\begin{array}{l}\text { Menthok-menthok gaya } \\
\text { berjalanmu }\end{array}$ & $\begin{array}{l}\text { (Tidak mengandung nilai } \\
\text { karakter tetapi lebih mengacu } \\
\text { pada sindiran secara halus) }\end{array}$ \\
\hline 8. & $\begin{array}{l}\text { Megal-megol gawe } \\
\text { guyu }\end{array}$ & $\begin{array}{l}\text { Lenggak lenggok } \\
\text { membuat tertawa }\end{array}$ & $\begin{array}{l}\text { - } \text { (Tidak mengandung nilai } \\
\text { karakter tetapi lebih mengacu } \\
\text { pada sindiran secara halus) }\end{array}$ \\
\hline
\end{tabular}

Pertama, menthok-menthok tak kandani, kata menthok-menthok memiliki arti entog. Menurut kamus online bahasa jawa Purwodarminto menthok merupakan sejenis unggas yang hampir mirip dengan bebek, namun jika diperhatikan badan entog atau menthok ini memiliki badan yang lebih besar, akan tetapi tidak sebesar angsa. Menurut Joyo seorang seniman dari Sanggar Cakraningrat Rembang yang dipimpin oleh Dalang Sigid dalam tembang dolanan menthok-menthok mengandung makna sindiran secara halus dengan menggunakan perumpamaan heman entog. Entog lebih banyak menghabiskan waktu untuk tidur dan tidak melakukan apa-apa, seperti manusia pemalas. Kata tak kandani memiliki arti memberi tahu. Pada lirik tembang ini memiliki makna memberi nasihat agar hidup disiplin dan tanggung jawab pada dirinya sendiri. Jika manusia tidak ingin hidupnya seperti menthok maka dalam kehidupan seharihari manusia harus aktif, disiplin dan bertanggung jawab atas kehidupannya tersebut. Kedua, mung rupamu angisin-isini, menurut kamus online bahasa jawa Purwodarminto kata mung dapat berarti hanya, kata rupamu memiliki arti wajahmu, sedangkan kata angisin-isini memiliki arti memalukan. Menurut Joyo seorang seniman dari Sanggar Cakraningrat Rembang yang dipimpin oleh Dalang Sigid, pada kata tersebut memiliki makna wajahmu hanya memalukan. Pada lirik ini bisa diartikan wajahmu sebagai gayamu hanya memalukan. Karena pada kalimat ini menggambarkan gaya nya hanya memalukan, artinya dengan tidak melakukan apapun dan hanya bersikap pasif dengan tingkat kepercayaan diri yang tinggi padahal dia hanya berdiam diri saja. Ketiga, mbok ya ojo ngetok, menurut kamus online bahasa jawa Purwodarminto kata mbokya memiliki arti seharusnya, kata ojo memiliki arti jangan, sedangkan kata ngetok memiliki arti terlihat atau kelihatan. Menurut Joyo seorang seniman dari Sanggar Cakraningrat Rembang yang dipimpin oleh Dalang Sigid, pada kalimat ini mengandung makna sindiran secara halus. Sindiran ini dimaksudkan sudah tidak berbuat apa-apa untuk apa terlihat, lebih baik tidak usah 
terlihat sekalian. Sindiran secara halus ini dimaksudkan agar menjaga perasaan dan tidak menyakiti hati tetapi harus tanggap dan dipahami.

Keempat, ana kandhang wae, menurut kamus online bahasa jawa Purwodarminto kata ana dapat berarti di, kata kandhang memiliki arti tempat tinggal menthok, sedangkan kata wae berarti saja. Menurut Joyo seorang seniman dari Sanggar Cakraningrat Rembang yang dipimpin oleh Dalang Sigid, pada kalimat ini menyatakan keterangan tempat yang merujuk pada tempat tinggal menthok, jika diibaratkan sebagai manusia, kandhang memiliki arti rumah tempat tinggal. Penggambarannya sama dengan sindiran secara halus, yaitu sudah tidak melakukan apapun dan lebih baik jangan terlihat cukup didalam rumah saja. Kelima, enak-enak ngorok, menurut kamus online bahasa jawa Purwodarminto kata ngorok dalam Bahasa Jawa memiliki arti mendengkur, dan mendengkur biasanya dilakukan saat tidur. Menurut Joyo seorang seniman dari Sanggar Cakraningrat Rembang yang dipimpin oleh Dalang Sigid, pada kalimat ini disisipkan sebuah sindiran halus. Sindiran halus ini mengungkapkan bahwa jika tidak ingin melakukan apapun atau biasa disebut malas lebih baik tidur saja. Pada kalimat sindiran tersebut ditujukan untuk manusia yang pemalas dan sukanya hanya tidur bahkan tidak melakukan apapun itu seperti bekerja. Keenam, ora nyambut gawe, menurut kamus online bahasa jawa Purwodarminto kata nyambut gawe dalam Bahasa Jawa memiliki arti melakukan pekerjaan. Pekerjaan merupakan sebuah kewajiban yang harus dilakukan untuk menghidupi dan mencukupi kebutuhannya sendiri. Jika seseorang tidak memiliki pekerjaan bisa disebut sebagai pengangguran dan tidak akan bisa menghidupi dirinya sendiri. menurut Joyo seorang seniman dari Sanggar Cakraningrat Rembang yang dipimpin oleh Dalang Sigid pada kalimat ini juga mengandung sindiran secara halus karena sudah tidak melakukan pekerjaan tetapi yang dilakukan hanya tidur saja.

Ketujuh, menthok-menthok mung lakumu, menurut kamus online bahasa jawa Purwodarminto kata mung lakumu memiliki arti hanya berjalanmu atau bisa dikatakan sebagai gaya berjalanmu. Menurut Joyo seorang seniman dari Sanggar Cakraningrat Rembang yang dipimpin oleh Dalang Sigid, pada kalimat ini ditujukan pada seseorang yang tidak melakukan apapun tadi dengan kepercayaan diri tinggi yang dimiliki dia begitu percaya dirinya dengan keadaan dia yang seperti itu. Kedelapan, megal megol gawe guyu, menurut kamus online bahasa Jawa Purwodarminto kata megal megol menjelaskan tentang cara berjalan dengan menggerakkan pinggul dengan lenggak lenggok. Kata gawe guyu memili arti membuat tertawa. Menurut Joyo seorang seniman dari Sanggar Cakraningrat Rembang yang dipimpin Dalang Sigid, pada kalimat megal megol gawe guyu memiliki arti cara berjalan lenggak lenggok yang membuat semua orang tertawa melihatnya. Kalimat ini menggambarkan tentang manusia yang tidak mau melakukan pekerjaan tetapi gaya berjalannya sangat percaya diri. Hasil analisis nilai karakter tembang dolanan. Terdapat nilai karakter yang terkandung dalam tembang dolanan "Gugur Gunung". Hasil analisisnya adalah sebagai berikut.

Tabel 2. Analisis Nilai Karakter yang Terdapat dalam Tembang Dolanan

\begin{tabular}{|c|c|c|}
\hline No & Lirik tembang & Terjemahan \\
\hline 1. & Ayo kanca ayo kanca & Ayo kawan ayo kawan \\
\hline 2. & Ngayahi karyane praja & $\begin{array}{l}\text { Melaksanakan } \\
\text { pekeriaan Negara }\end{array}$ \\
\hline 3. & Kene kene kene kene & $\begin{array}{l}\text { Kemari kemari kemari } \\
\text { kemari }\end{array}$ \\
\hline 4. & $\begin{array}{l}\text { Gugur gunung } \\
\text { tandhang gawe }\end{array}$ & $\begin{array}{l}\text { Tanggung jawab dan } \\
\text { gotong royong } \\
\text { melakukan pekeriaan }\end{array}$ \\
\hline 5. & Sayuk-sayuk rukun & Menciptakan kerukunan \\
\hline $\begin{array}{l}6 . \\
7 . \\
8 .\end{array}$ & $\begin{array}{l}\text { Bebarengan ro kancane } \\
\text { Lila lan legawa } \\
\text { Kanggo mulya ning } \\
\text { Negara }\end{array}$ & $\begin{array}{l}\text { Bersama dengan teman } \\
\text { Dengan rasa ikhlas } \\
\text { Untuk kesejahteraan } \\
\text { Negara }\end{array}$ \\
\hline 9. & Siji loro telu papat & Satu dua tiga empat \\
\hline
\end{tabular}

\author{
Nilai karakter \\ Disiplin \\ (mengajak) \\ Tanggung jawab \\ Disiplin \\ Disiplin \\ (mengajak) \\ Tanggung jawab \\ Gotong royong \\ Tanggung jawab \\ Disiplin \\ (kewajiban) \\ Tanggung jawab \\ Tanggung jawab \\ Tanggung jawab \\ (tidak termasuk nilai karakter \\ tetapi lebih mengacu pada \\ aba-aba semangat)
}


IVCEJ, Vol 4 No 1, Tahun 2021

p-ISSN: 2615-4684 e-ISSN: 2615-6938

\begin{tabular}{|c|c|c|c|}
\hline No & Lirik tembang & Terjemahan & Nilai karakter \\
\hline 10. & Maju papat papat & Maju empat empat & Disiplin \\
\hline 11. & Diulang ulangake & $\begin{array}{l}\text { Dikerjakan bersama } \\
\text { sama secara estafet }\end{array}$ & $\begin{array}{l}\text { Tanggung jawab } \\
\text { Disiplin }\end{array}$ \\
\hline 12. & $\begin{array}{l}\text { Mesthi enggal } \\
\text { rampunge }\end{array}$ & Agar cepat selesai & $\begin{array}{c}\text { Tanggung jawab } \\
\text { Disiplin }\end{array}$ \\
\hline 13. & Holobis kuntul baris & $\begin{array}{l}\text { Seperti kuntul yang } \\
\text { berbaris (aba-aba) }\end{array}$ & $\begin{array}{c}\text { Tanggung jawab } \\
\text { Disiplin }\end{array}$ \\
\hline
\end{tabular}

Pertama, Ayo kanca ayo kanca, menurut Joyo seorang seniman dari Sanggar Cakraningrat Rembang yang dipimpin oleh Dalang Sigid, kata ayo pada kalimat ini merupakan sebuah ajakan kepada orang lain, kalimat ajakan dapat ditujukan kepada siapapun, sedangkan kata kanca dalam kalimat tersebut menggambarkan teman atau kawan. Kalimat ini merupakan sebuah ajakan kepada teman atau kawan untuk melakukan sesuatu yang dilakukan bersamasama. Kalimat ini menjelaskan bahwa hidup manusia sebagai makhluk sosial yang artinya tidak dapat hidup sendiri tanpa bantuan orang lain. Kehidupan masyarakat terorganisasi secara rapi, dalam masyarakat Jawa tercermin nilai-nilai dalam budaya hormat dan rukun. Kedua, Ngayahi karyane praja, menurut Joyo seorang seniman dari Sanggar Cakraningrat Rembang yang dipimpin oleh Dalang Sigid kata ngayahi memiliki arti melaksanakan atau melakukan, kata karyane memiliki arti pekerjaan, sedangkan kata praja merujuk pada keterangan tempat, keterangan tempat yang dimaksudkan dalam tembang dolanan ini adalah Negara. Kalimat ini menjelaskan bahwa kata ngayahi karyane praja memiliki arti melaksanakan atau melakukan pekerjaan Negara, kalimat tersebut bermaksud mengajak untuk melaksanakan tugas Negara. Tugas Negara yang dimaksud merupakan bekerja sama melakukan tanggung jawab dan gotong royong menjaga lingkungan sekitar (Tanto et al., 2019).

Ketiga, Kene kene kene kene, menurut Joyo seorang seniman dari Sanggar Cakraningrat Rembang yang dipimpin oleh Dalang Sigid kata kene dalam kalimat ini memiliki arti kemari yang merupakan kalimat ajakan. Ajakan yang dimaksud adalah untuk bahu membahu melakukan sebuah pekerjaan. Ajakan ini dilakukan agar tingkat kesadaran pada diri seseorang dapat terwujud dengan adanya sikap saling tolong menolong serta bahu membahu dalam melalukan setiap pekerjaan untuk mencapai sebuah hasil yang dirasa dapat menguntungkan semua pihak. Keempat, Gugur gunung tandhang gawe, menurut kamus online bahasa jawa Purwodarminto kata gugur gunung memiliki arti kegiatan negara yang dilakukan orang pedesaan tanpa memberikan upah, kata tandhang memiliki arti melakukan atau melaksanakan, sedangkan kata gawe memiliki arti pekerjaan. Menurut Joyo seorang seniman dari Sanggar Cakraningrat Rembang yang dipimpin oleh Dalang Sigid kalimat tersebut menjelaskan bahwa gotong royong merupakan sebuah sikap tanggung jawab dan kewajiban setiap manusia untuk menjaga lingkungan sekitar. Tanggung jawab dengan cara bergotong royong melakukan atau melaksanaan sebuah pekerjaan bersama-sama. Semua pekerjaan yang berat akan terasa ringan jika dilakukan bersama-sama dengan rasa ikhlas. Memiliki arti tanggung jawab dan gotong royong melakukan pekerjaan secara bersama sama. Dalam proses ini terjadi saling bantu membantu antra warga masyarakat. Selain untuk membantu pekerjaan individu manusia, sikap tanggung jawab yang dihasilkan saat melaksanakan gotong royong seperti ini biasanya juga sering digunakan untuk menyelesaikan pekerjaan-pekerjaan untuk kepentingan sosial atau kepentingan bersama (Nuryanto, 2017).

Kelima, Sayuk sayuk rukun, menurut kamus online bahasa jawa Purwodarminto kata sayuk-sayuk memiliki arti menciptakan, sedangkan kata rukun disini berarti kerukunan. Menurut Joyo seorang seniman dari Sanggar Cakraningrat Rembang yang dipimpin oleh Dalang Sigid pada kalimat ini menjelaskan bahwa dalam kehidupan harus ada sikap menghargai dan bekerja sama untuk menciptakan sebuah kerukunan dalam bermasyarakat. Artinya bersatu membentuk sebuah kerukunan agar hidup bermasyarakat lebih baik dan tentram. Hal yang mendasari dalam pekerjaan yang dilakukan bersama-sama adalah adanya kerukunan antar warga masyarakat. Keadaan rukun berarti semua pihak berkeinginan dan bertindak ke arah suasanan damai, saling membantu dan bekerja sama, saling menerima dengan tenang dan sepakat. Keenam, Bebarengan ro kancane, menurut Joyo seorang seniman dari Sanggar Cakraningrat Rembang yang dipimpin oleh Dalang Sigid kata bebarengan memiliki arti bersama, kata ro berasal dari kata karo memiliki arti dengan, sedangkan kata kancane memiliki arti teman atau kawan. Kalimat bebarengan ro kancane merupakan bersama dengan teman, artinya jika sebuah pekerjaan dilakukan bersama teman atau orang lain maka pekerjaan tersebut akan cepat selesai. Berbeda jika pekerjaan yang dilakukan secara individual akan lambat untuk selesai. Dalam posisi hidup 
bermasyarakat, manusia tidak dapat bersifat individual. Hidup bermasyarakat tidak boleh mementingkan kepentingan pribadi, akan tetapi lebih giat dalam dalam melakukan kewajiban untuk menciptakan ketentraman dalam hidup bermasyarakat. memiliki arti melakukan sebuah pekerjaan secara bersama sama dengan teman.

Ketujuh, Lila lan legawa, menurut kamus online bahasa jawa Purwodarminto kata lila merupakan bentuk kesenangan hati, kata lan memiliki arti dan, sedangkan kata legawa memiliki arti ikhlas. Menurut Joyo seorang seniman dari Sanggar Cakraningrat Rembang yang dipimpin oleh Dalang Sigid kalimat ini menggambarkan sebuah perasaan ikhlas dan sabar dalam hati untuk melakukan setiap pekerjaan. Tanpa harus ada imbalan dan tanpa rasa pamprih. arti kata ini memiliki makna jika melakukan sebuah pekerjaan harus disertai dengan rasa ikhlas dan sabar dari dalam hati. Kedelapan, Kanggo mulya ning Negara, menurut Joyo seorang seniman dari Sanggar Cakraningrat Rembang yang dipimpin oleh Dalang Sigid kata kanggo memiliki arti untuk, kata mulya memiliki arti kesejahteraan. Pada kalimat ini menjelaskan bahwa pekerjaan yang dilakukan akan membuahkan hasil yaitu kesejahteraan Negara. Kesejahteraan Negara yang dimaksudkan adalah hidup rukun, tentram dan damai antar warga masyarakat sekitar. Upaya yang dilakukan dengan bersatu, bahu membahu, bergotong royong, tanggung jawab dan ikhkas akan menjadi kekuatan terbesar dalam rangka mencapai kejayaan Negara.

Kesembilan, Siji loro telu papat, menurut Joyo seorang seniman dari Sanggar Cakraningrat Rembang yang dipimpin oleh Dalang Sigid kata siji loro telu papat merupakan hitungan angka dalam Bahasa Jawa yang artinya satu dua tiga empat. Pada hitungan tersebut biasanya menggambarkan kekompakan yang diciptakan masyarakat saat melakukan pekerjaan secara bersama-sama. Kalimat ini dimaksudkan untuk menambahkan rasa semangat yang ada dalam diri seseorang saat melakukan pekerjaan secara bersamaan. Aba-aba dalam hitungan seperti ini biasa dilakukan agar menambah semangat suasana sekitar. Kesepuluh, Maju papat papat, menurut Joyo seorang seniman dari Sanggae Cakraningrat Rembang yang dipimpin oleh Dalang Sigid kata maju papat papat memiliki arti maju empat empat, ini berarti menggambarkan kondisi saat melakukan sebuah pekerjaan bersama yang dilakukan sekelompok masyarakat. Biasaya dalam melakukan pekerjaan terdapat lebih dari 10 orang yang melakukan. Pekerjaan ini tidak dilakukan oleh perorangan atau individu akan tetapi pekerjaan ini dilakukan secara kelompok.

Kesepuluh, diulang ulangake, menurut Joyo seorang seniman dari Sanggar Cakraningrat Rembang yang dipimpin oleh Dalang Sigid kata diulang ulangake mempunyai arti dilakukan secara estafet. Pada kalimat ini menjelaskan bahwa pekerjaan yang dilakukan secara estafet. Alasan menggunakan cara secara estafet agar mempersingkat waktu dan tidak banyak membuang tenaga. Kesebelas, Mesthi enggal rampunge,menurut Joyo seorang seniman dari Sanggar Cakraningrat Rembang yang dipimpin oleh Dalang Sigid kata mesthi memiliki arti pasti, kata enggal memiliki arti cepat sedangkan kata rampunge memiliki arti selesai. Pada kalimat mesthi enggal rampunge menjelaskan bahwa pasti cepat selesai. Maksudnya adalah apabila pekerjaan dilakukan secara bersama-sama pasti akan cepat terselesaikan. Bukan hanya agar cepat selesai, namun akan terasa ringan jika dilakukan secara bersama-sama. Keduabelas, Holobis kuntul baris, menurut kamus online bahasa jawa Purwodarminto kata kuntul disini memiliki arti burung kuntul. Biasanya habitat burung kuntul pada tanah pesawahan atau lahan yang bersifat basah. Menurut Joyo seorang seniman dari Sanggar Cakraningrat Rembang yang dipimpin oleh Dalang Sigid, pada kalimat ini menjelaskan bahwa kehidupan manusia diharuskan seperti burung kuntul yang selalu berkelompok, selain itu burung kuntul juga sangat kompak saat mencari makan. Jika saat terbang leher burung kuntul akan membentuk huruf "S". Mereka berbaris dengan kompak secara bersama-sama Holobis kuntul baris juga biasa diartikan sebagai aba-aba sebelum melakukan sebuah pekerjaan agar menumbuhkan rasa semangat yang besar pada diri seseorang.

\section{SIMPULAN DAN SARAN}

Berdasarkan hasil penelitian dalam deskripsi data dan pembahasan yang telah diuraikan oleh peneliti, maka dapat ditarik kesimpulan bahwa pada pada tembang dolanan "MenthokMenthok" dan "Gugur Gunung", banyak mengandung nilai karakter disiplin dan nilai karakter tanggung jawab serta terselip nilai karakter gotong royong bagi pembentukan karakter peserta didik. Melalui pembelajaran tembang dolanan dan maknanya dapat diketahui bahwa banyak sekali pesan moral yang terdapat dalam tiap lirik tembang yang berguna bagi pembentukan karakter peserta didik untuk memiliki sikap dan kepribadian yang disiplin dan tanggung jawab. Melalui pembelajaran Bahasa Jawa dengan materi tembang dolanan Jawa diharapkan dapat dijadikan sebagai salah satu usaha dalam pelestarian kebudayaan tradisional Jawa. Melalui 
bimbingan gurunya dalam pembelajaran Bahasa Jawa peserta didik dapat mengapresiasi tembang dolanan Jawa yang banyak mengandung nilai-nilai luhur sebagai pembentukan karakternya.

\section{DAFTAR PUSTAKA}

Arifin, M. Z., Ulfa, S., \& Praherdhiono, H. (2018). Pengembangan kurikulum muatan lokal karawitan sebagai upaya mengkonstruksi pengetahuan dan pelestarian budaya jawa di jenjang sma. Jurnal Kajian Teknologi Pendidikan, 1(2), 2-10. http://journal2.um.ac.id/index.php/jktp/article/view/3707.

Arisyanto, P., Prasetyo, S. A., Untari, M. F. A., \& Sundari, R. S. (2021). Pengembangan Media Pembelajaran Tembang Macapat Berbasis Android Bagi Mahasiswa PGSD UPGRIS. Jurnal Basicedu, 5(3), 1584-1592. https://doi.org/10.31004/basicedu.v5i3.945.

Dozan, W., \& Fitriani, L. (2020). Membangun Karakter Anak Usia Dini Melalui Nilai-Nilai Islam Dalam Tradisi Perang Timbung. Murhum. Jurnal Pendidikan Anak Usia Dini, 1(1), 1-15. https://doi.org/10.37985/murhum.v1i1.2.

Farid, M. N. (2012). Peranan Muatan Lokal Materi Batik Tulis Lasem Sebagai Bentuk Pelestarian Budaya Lokal. Komunitas. International Journal of Indonesian Society and Culture, 4(1). https://doi.org/10.15294/komunitas.v4i1.2400.

Gazali, N., Cendra, R., Candra, O., Apriani, L., \& Idawati, I. (2019). Penanaman Nilai-Nilai Karakter Peserta Didik Melalui Ekstrakurikuler Pramuka. Aksiologiya: Jurnal Pengabdian Kepada Masyarakat, 3(2), 201. https://doi.org/10.30651/aks.v3i2.1898.

Hidayah, N. (2015). Penanaman Nilai-nilai Karakter Dalam Pembelajaran Bahasa Indonesia di Sekolah Dasar. Jurnal Pendidikan Dan Pembelajaran Dasar, 2(2). https://doi.org/10.24042/terampil.v2i2.1291.

Khusniati, M. (2014). Model Pembelajaran Sains Berbasis Kearifan Lokal Dalam Menumbuhkan Karakter Konservasi. Indonesian Journal of Conservation, 3(1), 67-74. https://doi.org/10.15294/ijc.v3i1.3091.

Muhamad Nova. (2017). Character Education In Indonesia EFL Classroom Implementation and Obstacles. Jurnal Pendidikan Karakter, 7(2). https://doi.org/10.21831/jpk.v7i2.13650.

Nurohmah, A. N., \& Dewi, D. A. (2021). Penanaman Nilai Moral dan Karakter di Era Pandemi melalui Pendidikan dengan Mengimplementasikan Nilai-Nilai Pancasila. Journal of Education, Psychology and Counseling, 3(1), 119-128. https://ummaspul.ejournal.id/Edupsycouns/article/view/1305.

Nurwita, S. (2019). Analisis Nilai-Nilai Agama dan Moral Anak Usia Dini dalam Tayangan Film Kartun Upin dan Ipin. Jurnal Obsesi: Jurnal Pendidikan Anak Usia Dini, 3(2), 506. https://doi.org/10.31004/obsesi.v3i2.252.

Nuryanto, S. (2017). Peningkatan Nilai-Nilai Karakter dengan Metode Mendongeng Cas Cis Cus di Ba Aisyiyah Kaponan 2 Ponorogo. Journal of Nonformal Education and Community Empowerment, 3(1), 11-20. https://doi.org/10.24914/pnf.v3i1.8732.

Pakpahan, R., \& Fitriani, Y. (2020). Analisa Pemafaatan Teknologi Informasi Dalam Pemeblajaran Jarak Jauh Di Tengah Pandemi Virus Corona Covid-19. JISAMAR (Journal of Information System, Applied, Management, Accounting and Researh), 4(2), 30-36. http://journal.stmikjayakarta.ac.id/index.php/jisamar/article/view/181.

Pitaloka, D. L., Dimyati, D., \& Edi, P. (2021). Peran Guru dalam Menanamkan Nilai Toleransi pada Anak Usia Dini di Indonesia. Jurnal Obsesi : Jurnal Pendidikan Anak Usia Dini, 5(2), 1696-1705. https://doi.org/10.31004/obsesi.v5i2.972.

Prayogi, D. S., Utaya, S., \& Sumarmi, S. (2019). Internalisasi Kearifan Lokal Dalam Pembelajaran melalui Pengembangan Multimedia Interaktif Muatan Pembelajaran IPS. Jurnal Pendidikan: Teori, Penelitian, Dan Pengembangan, 4(11), 1457-1463.

Puspawati, G. A. M. (2019). Nilai-Nilai Pendidikan Karakter dalam Ragam Gerak Tari Pendet. Jurnal Stilistika, 7(2), 274-291. https://doi.org/10.5281/zenodo.3900648.

Ramdhani, S., Yuliastri, N. A., Sari, S. D., \& Hasriah, S. (2019). Penanaman Nilai-Nilai Karakter melalui Kegiatan Storytelling dengan Menggunakan Cerita Rakyat Sasak pada Anak Usia Dini. Jurnal Obsesi: Jurnal Pendidikan Anak Usia Dini, 3(1), 153. https://doi.org/10.31004/obsesi.v3i1.108.

Setyawan, A., Suwandi, S., Slamet, S. Y., Keguruan, F., Universitas, P., \& Maret, S. (2017). Muatan Pendidikan Karakter Dalam Cerita Rakyat Di Pacitan. Jurnal Pendidikan Karakter, 7(2), 199-211. https://doi.org/10.21831/jpk.v7i2.21778.

Sukarniti, N. L. K. (2020). Pewarisan Nilai-Nilai Kearifan Lokal Untuk Memproteksi Masyarakat 
IVCEJ, Vol 4 No 1, Tahun 2021

Bali Dari Dampak Kemajuan Teknologi. Jurnal Ilmiah Cakrawarti, 3(1), 39-50. https://doi.org/10.47532/jic.v3i1.135.

Tanto, O. D., Hapidin, H., \& Supena, A. (2019). Penanaman Karakter Anak Usia Dini dalam Kesenian Tradisional Tatah Sungging. Jurnal Obsesi : Jurnal Pendidikan Anak Usia Dini, 3(2), 337-345. https://doi.org/10.31004/obsesi.v3i2.192.

Wardani, Septiana, M., Nugroho, N. R. I., \& Ulinnuha, M. taufiq. (2019). Penguatan Pendidikan Karakter dalam Proses Pembelajaran Bahasa Inggris. Buletin Literasi Budaya Sekolah, 1(1), 27-33.

Yulianti, D., Khanafiyah, S., \& Sulistyorini, S. (2016). Inquiry-based science comic physics series integrated with character education. Jurnal Pendidikan IPA Indonesia, 5(1), 38-44. https://doi.org/10.15294/jpii.v5i1.5787. 